\title{
Study in the Development of Fixed Bed Filter Adoption of Public Health of Lake Water Users
}

\author{
Esthi KUSDARINI ${ }^{1}$, Lukman HAKIM ${ }^{2}$, \\ Bagyo YANUWIADI ${ }^{2}$ and Suyadi SUYADI, ${ }^{3, *}$ \\ ${ }^{I}$ Faculty of Environmental Science, Brawijaya University, Malang 65145, Indonesia \\ ${ }^{2}$ Faculty of Math and Science, Brawijaya University, Malang 65145, Indonesia \\ ${ }^{3}$ Faculty of Animal Husbandry, Brawijaya University, Malang 65145, Indonesia
}

('Corresponding author's e-mail: suyadi@ub.ac.id)

Received: 10 November 2019, Revised: 17 June 2020, Accepted: 15 July 2020

\begin{abstract}
Lake water consumed by the community in the Gresik upland area, Indonesia, contains contaminants that exceed the quality threshold. This research focuses on factors that can influence people's actions to adopt fixed bed filters and highlights strategies for the community to be willing to treat lake water before consuming it. This study builds an adoption of a fixed bed filter model and examines the effect of 15 factors (independent variables) on community actions to adopt the tool. A total of 248 samples from 3 villages were randomly selected to test the hypothesis. Data is collected, sorted, and analyzed statistically. Data analysis uses descriptive statistics and multiple linear regression analysis. Data representation, validation, and correlation of data are carried out in MS Excel and SPSS. The adoption of the fixed bed filter model shows that of the 15 factors analyzed, 3 factors significantly influenced the adoption decision (Sig. $<0.05$ ): The elements, namely, attitudes toward water treatment, availability of infrastructure, and government assistance. One factor influences the decision on tool adoption quite significantly ( Sig. < 0.1), namely the innovation of the lake water management agency. Several elements can carry out the development of the passage of fixed bed filters: Socializing contaminated water and water treatment, procurement of tools, assisting the adoption of tools, increasing the government's active role, and improving the performance of the lake water management agency. This model can be used to make the adoption of water treatment equipment models in other areas.
\end{abstract}

Keywords: Contaminants, Fixed bed filters, Lake, Multiple linear regression, Water treatment

\section{Introduction}

Communities in 3 villages, namely Metatu, Sirnoboyo, and Kalipadang Village (Gresik, Indonesia), use lake water to have clean drinking water. Most of the lake water in this area contains turbidity, color, surfactant, total organic, E. coli, and total coliform exceeding the maximum water and drinking water requirements $[1,2]$. While a small portion contains $\mathrm{Cr}$ and $\mathrm{Pb}$, these levels also exceed the maximum limit required. Heavy metals such as $\mathrm{Cr}$ and $\mathrm{Pb}$ at certain levels can accumulate in the body and endanger the health of humans who consume the lake water [3]. A surfactant such as a detergent component that is toxic also threatens the health of humans who consume the lake water [4].

Furthermore, E. coli and total coliform indicate the presence of pathogenic bacteria in water, which can cause various diseases for humans who consume the lake water [5]. Besides, the turbidity and colour of the lake water also decrease the aesthetics of the water. Therefore, this lake water must be treated before consumption. 
http://wjst.wu.ac.th

Lake water treatment must be carried out so that the community's water meets the health requirements of the Regulations by the Minister of Health of the Republic of Indonesia and WHO [5,6]. Several methods can be chosen to reduce lake water contaminants, including coagulation-flocculation [8], cation exchange [8,9], adsorption [10-12], and filtration [14]. The government once tried to do lake water treatment using a filtration process. Still, the community was not ready to adopt this treatment tool or technology that they abandoned the tool at the edge of the lake. Chukumnird et al. explain that a person's behaviour can be studied as the factors influencing behaviour [15]. Therefore, to treat the lake water, it is necessary to know the factors influencing the community's decision to adopt water treatment equipment or technology [16]. The study explained that knowledge, desire, perception and attitude, experiment, application, confirmation were the stages that were passed in the adoption process. These stages were estimated as factors that able to influence a person's decision to adopt a new tool or new technology [1719]. Another study also explained that attitudes could change into action if there were other facilities [18]. This research is vital because it develops the adoption model of water treatment equipment and determines steps that can be taken so that the culture of adoption of water treatment equipment can be realized and people can live healthier lives.

The culture of adopting water treatment equipment can be realized if the conditions that make people want to adopt water treatment equipment have been fulfilled. Several studies have been conducted to study the factors influencing the adoption of water treatment equipment or technology in various regions with different community characteristics and cultures [15-18]. The research conducted in Ghana explained that equipment prices, equipment attributes, and institutions influenced new technology adoption [20]. The study conducted in a rural area in Nusa Tenggara, Indonesia, also explained that institutional, education, and economic, social level influenced society's decision to adopt clean water technologies [21,24]. Furthermore, the research, which was implemented in the urban area of Ghana explained that the raw water availability and equipment price influenced society's decision to adopt water distribution technology [25]. The study, which was conducted in urban areas of Cary, North California, explained that infrastructure influenced the adoption development of water use technology [22]. The study in Taman Wisata Alam, Sintang, West Borneo, Indonesia described that institution and government role influenced the development of the use of water source technology [26]. The research in 3 locations (a city in Greece, airports in Italy, and water utilities in the Netherlands) highlighted that environment, institution, and individuals influenced the adoption of water supply technology [27]. Several different factors influenced societies' decision to adapt equipment for different conditions and had a different condition, so this research was very important.

This research built a model for adopting water treatment equipment (filter equipment) with data samples in rural communities in the Gresik dry land area, East Java, Indonesia, which was directed to know the influence factors of the society's decision to adopt water treatment equipment. People in the Gresik area have unique cultural, social, and environmental characteristics and are different from research conducted in other regions or countries. Lake water is the primary water source in this dry land area. Therefore, the adoption of water treatment equipment or technology is essential to maintain the health of the local community.

\section{Materials and methods}

\section{The sample and research location}

The sample of this research is the users of the lake water in the community villages of Benjeng District, Gresik Regency, East Java, Indonesia. The study locations are presented in Figure 1. Sampling was taken randomly based on the village cluster (Cluster Random Sampling), namely 88 people (Metatu Village), 80 people (Sirnoboyo Village), and 80 people (Kalipadang Village). 


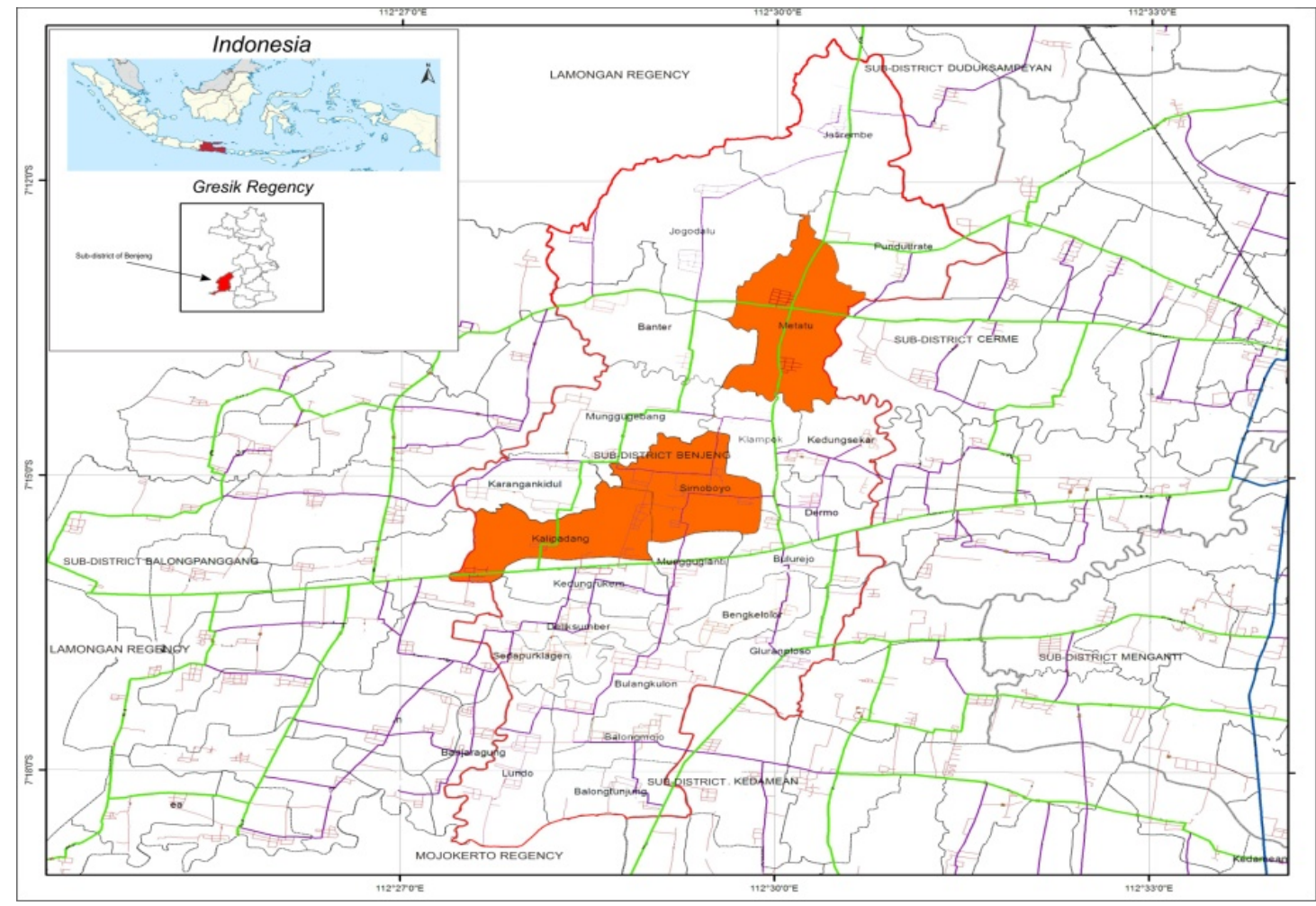

Figure 1 Research location (Metatu, Sirnoboyo, and Kalipadang Village).

\section{Research Instruments and validity test}

This study tested the influence of 15 factors or independent variables on dependent factors (decision to adopt water treatment equipment). The determination of 15 factors or independent variable based on the research has been done [22]. The questionnaire consisted of 15 questions regarding the characteristics of respondents ( 2 items), perceptions of water treatment equipment ( 5 issues), raw water and infrastructure (4 questions), the role of the government ( 2 questions) and the role of the lake water management agency ( 2 items). The answers to the questionnaire were choices on a Likert Scale from 1 (strongly disagree) to 5 (strongly agree). Validity is measured based on the Pearson rxy Correlation coefficient. The questionnaire was declared valid if the Pearson rxy Correlation coefficient was higher than the cutoff or $r$ table [28]. Reliability was measured based on Cronbach's alpha, and the questionnaire was declared reliable if the value was more significant than 0.60 [29].

\section{Data analysis}

The testing of the influence of 15 factors in the community's decision to adopt a water treatment tool is conducted using multiple linear regression analysis with SPSS software version 23. Fifteen of these factors are age (X1), education (X2), knowledge of water treatment (X3), attitude towards processing water (X4), attitudes toward the performance of water treatment equipment (X5), attitude towards the placement of sample equipment (X6), satisfaction with the economic value of the material (X7), availability of raw water (X8), availability of facilities and infrastructure (X9), lake maintenance (X10), a piping network for water distribution (X11), government care (X12), government assistance (X13), vision and mission of the water management agency (X14), the innovation of the water management agency (X15). Before performing a regression analysis, the following assumptions were tested: 
http://wjst.wu.ac.th

1. Testing the normality assumption to test whether the regression model, the residual variance is normally distributed or not. Testing using the Normal Probability Plot (P-P plot).

2. Testing the assumption of heteroscedasticity to determine whether residuals have homogeneous variations or not. Testing uses the Spearman Correlation test [28].

3. Multicollinearity testing is intended to determine whether there is a relationship between independent variables. The test uses Tolerance and Variance Inflation Factor (VIF) values [30].

After testing the assumptions, multiple regression analysis was carried out (T-test and F-test). Furthermore, the contribution of factors or independent variables on the dependent variable were tested using the coefficient of determination. The regression analysis was selected because of the impact of several independent variables on the dependent variable that has been widely studied in different contexts (Chantana et al., 2019; Lucas et al., 2019;' Mehmanpazir et al., 2019; Peng, 2019),

$$
Y=a+b 1 X 1+b 2 X 2+\ldots .+e
$$

where: $\mathrm{Y}$ is the dependent variable, which is the variety of people's perception of water filters. $\mathrm{X}$ is an independent variable or factor, such as age (X1), education (X2), knowledge of water treatment (X3), attitude towards processing water (X4), et al. Whereas a, b, and e are constants.

The test criteria state that if the probability value is less than the level of significance $(\alpha=5 \%)$, then the influence of the independent variable on the dependent variable is stated [28].

\section{Results and discussion}

This study aims to study the factors that influence the community's decision to adopt a water treatment plant through the development of a model.

1. General information on the sample. The samples came from 3 villages, namely Metatu Village, Sirnoboyo Village, and Kalipadang Village. The sample of the male as much as 55 and $45 \%$ of women. Samples aged 16 - 35 years were $37 \%$, 36 - 55 years were $56 \%$, and over 55 years was $7 \%$.

2. Descriptive statistics of respondents' responses to questionnaire questions are presented in Table $\mathbf{1 .}$

Table 1 Descriptive statistics of respondents' responses.

\begin{tabular}{lccc}
\hline \multicolumn{1}{c}{ Variable } & Min & Max & Mean \\
\hline Age (X1) & 16.00 & 87.00 & 40.6383 \\
Education (X2) & 6.00 & 21.00 & 9.7004 \\
Knowledge of water treatment (X3) & 1.00 & 5.00 & 4.3347 \\
Attitudes to water treatment (X4) & 2.00 & 5.00 & 4.3806 \\
Attitudes to the performance of water treatment equipment (X5) & 2.00 & 5.00 & 4.2236 \\
Attitude to sample device placement (X6) & 1.00 & 5.00 & 3.8219 \\
Satisfaction with the economic value of the tool (X7) & 2.00 & 5.00 & 3.8421 \\
Availability of raw water (X8) & 2.00 & 5.00 & 3.9190 \\
Availability of facilities and infrastructure (X9) & 2.00 & 5.00 & 4.1639 \\
Pond maintenance (X10) & 2.00 & 5.00 & 4.3171 \\
Piping network for water distribution (X11) & 3.00 & 5.00 & 4.2551 \\
Government Concern (X12) & 3.00 & 5.00 & 4.2308 \\
Government aid (X13) & 3.00 & 5.00 & 4.3036 \\
Vision and mission of the water management agency (X14) & 2.00 & 5.00 & 4.1613 \\
Water management agency innovation (X15) & 2.00 & 5.00 & 4.1984 \\
Tool adoption (Y) & 2.00 & 5.00 & 4.3239 \\
\hline
\end{tabular}


1. Validity testing showed that all questions in the questionnaire were valid with a Pearson Correlation coefficient between 0.533 - 1,000, while the cutoff was 0.1381 [28]. Reliability testing also showed that all questionnaire questions were reliable, with Cronbach's alpha between $0.649-0.784$, so that it was higher than 0.6 [29].

2. Testing the assumption of normality showed that the residuals were normally distributed. Testing heteroscedasticity assumptions showed that residuals had homogeneous variations because all independent variables produced probabilities of $0.067-0.977$. Thus, they were higher than the level of significance $(\alpha=5 \%)$. The test of the multicollinearity assumption showed that there was no relationship between the independent variables. There were no symptoms of multicollinearity because all independent variables produced Tolerance values greater than 0.1 , and VIF was smaller than 10 [30].

3. The results of the multiple regression, linear tests (T-test) are presented in Table 2. The T-test showed that attitudes toward water treatment, availability of facilities and infrastructure, and government assistance significantly influence (Sig. $<0.05)$ the community's decision to adopt water treatment equipment. While the innovation of the lake water management agency, significantly influenced (Sig. < 0.1 ) the adoption of water treatment equipment by the community.

Table 2 Linear multiple regression test results (T-test).

\begin{tabular}{lccc}
\hline \multicolumn{1}{c}{ Variable } & Coefficients & T Statistics & Sig. \\
\hline (Constant) & 1.636 & 2.924 & 0.004 \\
Age (X1) & -0.003 & -1.040 & 0.300 \\
Education (X2) & $6.522 \mathrm{E}-5$ & 0.005 & 0.996 \\
Knowledge of water treatment (X3) & 0.002 & 0.029 & 0.977 \\
Attitudes to water treatment (X4) & 0.126 & 2.031 & $\mathbf{0 . 0 4 4}$ \\
Attitudes to the performance of water treatment equipment (X5) & 0.094 & 1.526 & 0.129 \\
Attitude to sample device placement (X6) & -0.086 & -1.461 & 0.146 \\
Satisfaction with the economic value of the tool (X7) & -0.080 & -1.481 & 0.140 \\
Availability of raw water (X8) & 0.036 & 0.556 & 0.579 \\
Availability of facilities and infrastructure (X9) & 0.132 & 2.271 & $\mathbf{0 . 0 2 4}$ \\
Pond maintenance (X10) & 0.010 & 0.138 & 0.890 \\
Piping network for water distribution (X11) & 0.018 & 0.230 & 0.819 \\
Government Concern (X12) & 0.049 & 0.788 & 0.431 \\
Government aid (X13) & 0.156 & 2.380 & $\mathbf{0 . 0 1 8}$ \\
Vision and mission of the water management agency (X14) & 0.090 & 1.460 & 0.146 \\
Water management agency innovation (X15) & 0.103 & 1.697 & 0.091 \\
\hline
\end{tabular}

4. While the results of the multiple linear regression test (F-test) are presented in Table 3. The Ftest showed that the 15 factors or variables tested in the model significantly influenced the community's decision to adopt a water treatment plant (Sig. $<0.05$ ). 
http://wjst.wu.ac.th

Table 3 Linear multiple regression test results (F- test).

\begin{tabular}{lccccc}
\hline & Sum of Squares & Df & Mean Square & F & Sig. \\
\hline Regression & 14.586 & 15 & 0.972 & 4.820 & 0.000 \\
Residual & 38.936 & 193 & 0.202 & & \\
Total & 53.522 & 208 & & & \\
\hline
\end{tabular}

5. Testing the coefficient of determination showed that the R-square in the model was $27.3 \%$. This showed that the adoption of the tool could be explained by 15 factors or variables tested by $27.3 \%$. Partial testing result (T-test) was presented in Figure 2.

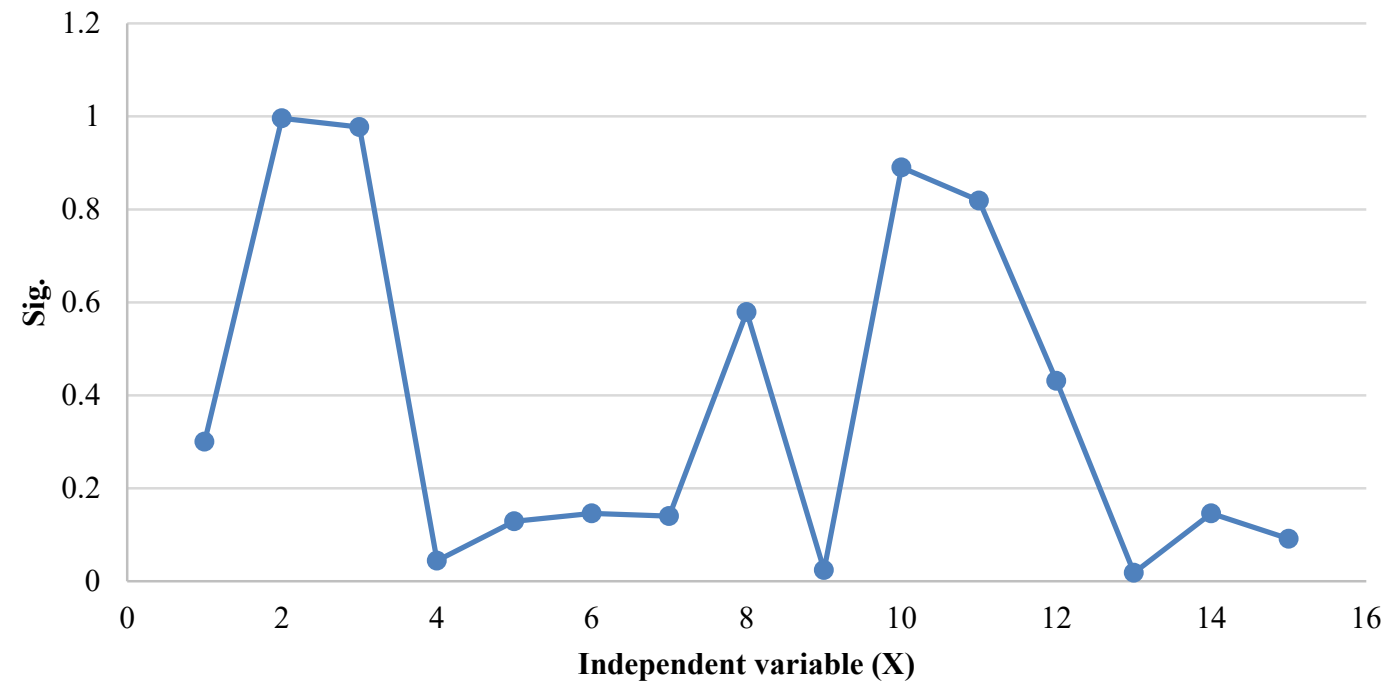

Figure 2 Sig. vs independent variable of T-test results.

The T-test results showed that among the 15 factors or variables studied, 3 factors significantly influenced (Sig. $<0.05$ ) the community's decision to adopt a water treatment plant. These 3 factors are the attitude towards water treatment, the availability of infrastructure, and government assistance. Furthermore, there is a 1 -factor influence that is quite significant (Sig. $<0.1)$ to the community's decision to adopt the tool. This factor is the innovation of water management institutions (Table 2). At the same time, the F-test showed that all independent variables (X1 to X15) significantly influenced the dependent variable (decision to adopt water treatment equipment). F-test result in this study was data that have to function to develop this research if the questionnaires were distributed to different group societies.

Furthermore, the T-test obtained the same findings as the previous research to influence infrastructure [22], government aid [26], and innovation of water treatment institutions [27]. The new finding in this study was the researchers found the factor of society's attitude to the water treatment, influencing society's decision to adopt water treatment equipment. This news finding supported behaviour theory which explained that attitude could change into another attitude if it supported with other facilities [18].

It showed that the attitude of a person after receiving a stimulant in the form of the introduction of water treatment equipment and performance is not enough to influence the person's decision to adopt water treatment equipment. Other factors influence the decision to adopt the tool, namely the availability 
http://wjst.wu.ac.th

of infrastructure, government assistance, and the lake water management agency's innovation. Infrastructure facilities in question include electricity, roads, water distribution systems, and, most importantly, the availability of water treatment equipment itself [18]. The availability of the infrastructures and innovations of lake water management institutions is greatly influenced by government policy. The government has a significant role in regulating, co-operating with, mobilizing, and involving all stakeholders who have a role in adopting the water treatment plant [35]. Stakeholders in question include the community of users of lake water, community leaders, management of lake water management institutions, Corporate Social Responsibility (CSR) of the company around the study sites, researchers, service providers of water treatment equipment and services, non-governmental organizations, and the government itself. Most of the facilities and infrastructure in the study location are the responsibility of the government, such as electricity and roads. The establishment of a lake water management agency is also with the government's approval.

Although the government has a significant role in influencing the community's decision to adopt water treatment equipment, the government cannot force people to adopt the material. The culture of adoption of this tool can be realized if awareness arises in the community of the importance of water treatment. Therefore, it is necessary to direct the public about the quality of the lake water they consume. The socialization topic could be focused on how the quality of clean water and drinking water required by the Republic of Indonesia's Minister of Health Regulation No. 32 of 2017 and WHO, as well as the danger of contaminants contained in lake water when consumed by humans both for the short and long term [5,6] is. This socialization can be carried out in collaboration between the government, nongovernmental organizations, lake water management institutions, community leaders, and other stakeholders. Socialization can be done by directly inviting the public to planned outreach meetings.

Besides, the community must be involved in every adoption process, such as the procurement and installation of water treatment equipment. The cost of procuring equipment can be obtained from nongovernmental organizations, assistance from the government, CSR around the company, nongovernmental organizations, donors, and other sources. The more aid funds for procurement of equipment collected, it will encourage the realization of water treatment equipment adoption. To find out the community's ability to contribute to the cost of this tool, further research is needed on the socio-economic community, following a study conducted by Sileshi et al. [21]. After sufficient water treatment equipment is available, assistance is needed during the adoption process. It is to prevent the cessation of water treatment equipment that is already available due to various obstacles in the field.

Assistance to the community as the adopter of water treatment equipment should be done for a minimum of 1 year. It is to prevent the failure of the adoption of water treatment equipment. In addition to the government, water management institutions' role is also critical in realizing the growth of a culture of adoption of water treatment equipment in the community. It is consistent with research conducted by Darkwah et al. [20] and Sileshi et al. [21]. The lake water management agency in this area is called the Drinking Water Population Association. The results showed that this institution's innovation was quite significant in supporting the realization of the adoption of water treatment equipment. This institution serves the community by distributing lake water. The innovation of water management institutions in distributing and processing lake water before distribution influences the realization of the culture of adopting water treatment equipment.

The culture of adopting water treatment equipment in the community of lake water users in the Gresik area should not be too difficult to realize. It is shown that from the 15 factors studied, only 4 factors influence the community's decision to adopt the tool. The community is not too concerned about the water treatment equipment to be adopted. The essential things are that this tool can treat the lake water well; the cost of procuring, operating, and repairing equipment is still affordable by the community; and there are institutions trusted by the community to handle the problem of processing and distributing lake water. Other researchers at different research sites can use the method used by researchers in finding factors that influence the adoption of water treatment equipment or technology. 
http://wjst.wu.ac.th

\section{Conclusions}

Water treatment equipment used to reduce turbidity, colour, surfactant, totally organic, E. coli, and total coliform lake water were simply fixed bed water filters, namely FRC (fibreglass reinforced plastic) filter tube which contained 3 media, namely manganese, zeolite, and active carbon. Furthermore, to reduce E. coli and total coliform content, you could add chlorine tablets to the water processed. The cost of procuring equipment for the 3,000 L/h capacity was $\mathrm{Rp} 2.800 .000,00$. Although procuring equipment was quite cheap and tool operation was quite easy, we must still maintain and control the tools regularly. The maintenance of the tools was quite easy, and by doing a backwash once a week, the community needed accompaniment during the process of developing a culture in tools adoption.

Factors influencing the community's decision to adopt a fixed-bed filter are attitudes towards water treatment, availability of facilities and infrastructure, government assistance, and the lake water management agency's innovation. These 4 factors have important implications for adopting fixed bed filters by the lake water user community. Therefore, as the policymaker in the provision of clean water for the community, the government should lead the stakeholders to work together in conducting socialization, procurement of tools, and assistance in the process of adopting tools. Support with the community's use of fixed bed filters for at least one year or until the lake water management agency and the local community can process and distribute the lake water independently, and this practice has become their daily habits and culture. Stakeholders in question include community leaders, management of lake water management institutions, non-governmental organizations, CSR companies, researchers, water treatment equipment providers, water treatment service providers, and other institutions related to this activity.

\section{Acknowledgements}

The authors would like thank the Institute of Education Fund Management, Ministry of Finance of the Republic of Indonesia, for funding this research. The authors would also like to thank the public water users who have participated in this study.

\section{References}

[1] E Kusdarini, S Suyadi, B Yanuwiadi and L Hakim. Analysis of water sources availability and water quality in dry and rainy season in dry land areas, North Gresik, Indonesia. Pollut. Res. 2019; 38, 58-65.

[2] E Kusdarini, S Suyadi, B Yanuwiadi and L Hakim. The supply of clean water and the problems in Benjeng sub-district, Gresik, Indonesia. In: Proceedings of the $13^{\text {th }}$ International Interdisciplinary Studies Seminar, Malang, Indonesia. 2019, p. 1-7.

[3] M Chabukdhara and AK Nema. Assessment of heavy metal contamination in Hindon River sediments: A chemometric and geochemical approach. Chemosphere 2012; 87, 945-53.

[4] M Wang, G Tan, A Eljaszewicz, Y Meng, P Wawrzyniak, S Acharya, C Altunbulakli, P Westermann, A Dreher, L Yan, C Wang, M Akdis, L Zhang, KC Nadeau and CA Akdis. Laundry detergents and detergent residue after rinsing directly disrupt tight junction barrier integrity in human bronchial epithelial cells. J. Allergy Clin. Immunol. 2019; 143, 1892-903.

[5] R Clarke, D Peyton, MG Healy, O Fenton and E Cummins. A quantitative microbial risk assessment model for total coliforms and E. coli in surface runoff following application of biosolids to grassland. Environ. Pollut. 2017; 224, 739-50.

[6] Menteri Kesehatan Republik Indonesia. Peraturan menteri kesehatan Republik Indonesia nomor 32 tahun 2017. Menteri Kesehatan Republik Indonesia, p. 1-31.

[7] WHO. Guidelines for drinking-water quality. $4^{\text {th }}$ ed. 2011, p. 564.

[8] B Ma, W Xuea, C Hua, H Liud, J Qua and L Li. Characteristics of microplastic removal via coagulation and ultrafiltration during drinking water treatment. Chem. Eng. J. 2019; 359, 59-167.

[9] E Kusdarini, DY Purwaningsih and A Budianto. Adsorption of $\mathrm{Pb}^{2+}$ Ion in water well with amberlite Ir 120 Na resin. Pollut. Res. 2018; 37, 307-12.

[10] E Kusdarini and A Budianto. Removal of manganese from well-water on Pasuruan, East Java, Indonesia using fixed bed cation exchanger and prediction of kinetics adsorption. Indian J. Sci. 
http://wjst.wu.ac.th

Technol. 2018; 11, 1-7.

[11] E Kusdarini, A Budianto and D Ghafarunnisa. Produksi karbon aktif dari batubara bituminus dengan aktivasi tunggal $\mathrm{H}_{3} \mathrm{PO}_{4}$, kombinasi $\mathrm{H}_{3} \mathrm{PO}_{4}-\mathrm{NH}_{4} \mathrm{HCO}_{3}$, dan termal. Reaktor 2017; 17, 74-80.

[12] A Budianto, E Kusdarini, S Effendi and M Aziz. The production of activated carbon from Indonesian mangrove charcoal. Mater. Sci. Eng. 2019; 462, 1-8.

[13] M Nitsae, ADR Madjid, L Hakim and A Sabarudin. Effect of tripolyphosphate and ethylene glycol diglicidyl ether on chitosan beads for Cr (VI) adsorption. Natural B 2016; 3, 220-5.

[14] RP Freitas de Oliveira and F Schneider. Slow sand filtration for biofouling reduction in seawater desalination by reverse osmosis. Water Res. 2019; 155, 474-86.

[15] S Chukumnird, U Boonyasopun and K Sirisom. Factors influencing adherence to preventive behaviors among Thais with hypertension: A literature review. Walailak J. Sci. \& Tech. 2019; 16, $509-21$.

[16] TS Rini, A Rachmansyah, AW Muhaimin and S Suyadi. Participation of waste pickers in waste management: A case study at randegan landfill Mojokerto, Indonesia. World Appl. Sci. J. 2013; 25, 1036-43.

[17] CJ Wright, JM Sargeant, VL Edge, JD Ford, K Farahbakhsh, I Shiwak, C Flowers, AC Gordon, RICG, IHACC Research Team, SL Harper. How are perceptions associated with water consumption in Canadian Inuit? A cross-sectional survey in Rigolet, Labrador. Sci. Total Environ. 2018; 618, $369-78$.

[18] S Notoatmodjo. Ilmu perilaku kesehatan. Rineka Cipta, 2010.

[19] Rahmaddin MY, T Hidayat, B Yanuwiadi and Suyadi. Knowledge, attitude, and action of community towards waste management in River Bank of Martapura. Int. J. Appl. Psychol. 2015; 5, 96-102.

[20] KA Darkwah, JD Kwawu, F Agyire-Tettey and DB Sarpong. Assessment of the determinants that influence the adoption of sustainable soil and water conservation practices in Techiman Municipality of Ghana. Int. Soil Water Conserv. Res. 2019; 7, 248-57.

[21] M Sileshi, R Kadigi, K Mutabazi and S Sieber. Determinants for adoption of physical soil and water conservation measures by smallholder farmers in Ethiopia. Int. Soil Water Conserv. Res. 2019; 7, $354-61$.

[22] VK Kandiah, EZ Berglund and AR Binder. An agent-based modeling approach to project adoption of water reuse and evaluate expansion plans within a sociotechnical water infrastructure system. Sustain. Cities Soc. 2019; 46, 101412.

[23] N Namprom, W Picheansathian, U Jintrawet and J Chotibang. Maternal participation program for enhancing growth and neurobehavioral development of very and moderately preterm infants: A case study. Walailak J. Sci. \& Tech. 2019; 16, 523-33.

[24] JJ Messakh and HC Zakarias. Effect of educational factors on the use of clean water in rural communities in the dry tropical areas, east Nusa Tenggara-Indonesia. Ecol. Environ. Conserv. Pap. $2019 ; 25,92-7$

[25] IA Bediako, X Zhao, HA Antwi and CN Mensah. Urban water supply systems improvement through water technology adoption. Technol. Soc. 2018; 55, 70-7.

[26] Antonius, A Hakim, AS Leksono and E Setyowati. Policy implementation of water resources utilization in nature tourist park sintang regency, West Kalimantan, Indonesia. Management 2018; 8, $1-6$.

[27] M Tutusaus, K Schwartz and S Smit. The ambiguity of innovation drivers: The adoption of information and communication technologies by public water utilities. J. Clean. Prod. 2018; 171, S79-S85.

[28] VW Sujarweni. SPSS untuk Penelitian. Pustaka Baru Press, Yogyakarta, 2015.

[29] J Hair, R Anderson, R Tatham and W Black. Multivariate data analysis. $5^{\text {th }}$ ed. Prentice Hall, New Jersy, 1998.

[30] M Kutner, C Nachtsheim and J Neter. Applied linear regression models. $4^{\text {th }}$ ed. The McGraw-Hill Company, New York, 2004.

[31] J Chantana, Y Kawano, A Kamei and T Minemoto. Description of degradation of output 
http://wjst.wu.ac.th

performance for photovoltaic modules by multiple regression analysis based on environmental factors. Optik (Stuttg) 2019; 179, 1063-70.

[32] SA Lucas, CC Lee, and E Love. Characterising recycled organic and mineral materials for use as filter media in biofiltration systems. Water 2019; 11, 1-19.

[33] F Mehmanpazir, K Khalili-Damghani and A Hafezalkotob. Modeling steel supply and demand functions using logarithmic multiple regression analysis (case study: Steel industry in Iran). Resour. Policy 2019; 63, 101409.

[34] JJ Peng. Factors affecting carbon emissions in the construction industry based on STIRPAT Model: Taking Henan province of China as an Example. Nat. Environ. Pollut. Technol. 2019; 18, 1035-40.

[35] G Sedia, Z Fanani, W Hasanah and H Niswatin. Village's forest conservation concept with local wisdom at ensaid Panjang village, Kelam Permai, West Kalimantan. IOSR J. Hum. Soc. Sci. 2018; 23, $12-24$ 